\title{
Optimization of Huff-n-Puff Gas Injection in a Shale Gas Condensate Reservoir
}

\author{
Xingbang Meng, James J. Sheng ${ }^{*}$, Texas Tech University \\ *Corresponding author, james.sheng@ttu.edu, phone: 8068348477
}

\begin{abstract}
Condensate blockage is a serious problem in shale gas condensate reservoirs. As the pressure decreases lower than dew point pressure, condensate forms. This condensate reduces the relative permeability of gas and the productivity of shale gas condensate reservoirs.

Huff-n-puff gas injection is an EOR method in which a well alternates between injection, soaking, and production. Based on the laboratory study conducted by Meng et al. (2015), huff-npuff gas injection was proven as an effective method to enhance condensate recovery for Eagle Ford shale cores. In this paper, a numerical reservoir simulation study is conducted to optimize the application of huff-n-puff gas injection in an Eagle Ford shale gas condensate reservoir. During the injection and soaking process, the pressure of the reservoir s built up, the condensate was revaporized to gas, and then was produced during the production process. Different parameters were investigated including injection time, soaking time, production time, and cycle numbers.

The results show that huff-n-puff gas injection is an effective method to enhance condensate recovery in the Eagle Ford shale gas condensate reservoir. It was found that the optimum injection time is the time during which the pressure of the main condensate region can be increased higher than dew point pressure. Also, shorter or even no soaking is more effective. The production time depends on the production decline rate. It is more profitable to start another cycle of huff-n-puff gas injection when the production rate is decreased to a low value.
\end{abstract}

\section{Introduction}

Kuenen (1892) used the term "retrograde condensation" to describe the anomalous behavior of a mixture that forms a liquid by an isothermal decrease in pressure, or by an isobaric increase in temperature. Kurata and Katz (1942) gave the most concise and relevant discussion of retrograde phenomena related to petroleum engineering. Retrograde vaporization can be used to describe the formation of vapor by an isothermal increase in pressure or by an isobaric decrease in temperature. Neither form of retrograde behavior occurs in single component systems. Gas condensate reservoirs typically exhibit GOR's between 3000 and 150000 scf/STB and liquid gravities between 40 and $60^{\circ}$ API (Standing, 1977; Moses, 1986).

For a gas condensate reservoir only gas normally exists in the reservoir, as the pressure is higher than the dew point pressure. When the pressure is decreased lower than the dew point pressure, the heavy components of reservoir fluids could be condensed, and a liquid phase could be formed in the reservoir. This formed liquid is named condensate. Liquid dropout will continue to increase until the pressure reaches a specific value. At this pressure, the maximum liquid dropout has accumulated in the reservoir. After this occurs, further pressure reduction will revaporize most of the condensed liquid-condensate. 
These conclusions assume that the overall composition of the reservoir mixture remains constant during depletion. In reality, the behavior of liquid dropout differs from that suggested by constant composition analysis. The condensate saturation is usually less than the saturation needed to mobilize the liquid phase. This is because the heavier components in the original mixture constitute most of the immobile condensate saturation and the overall molecular weight of the remaining reservoir fluid increases during depletion. This also makes the condensate accumulate in the formation, and reduces the relative permeability of gas. The productivities of gas and liquid in gas condensate reservoirs are reduced due to this condensate accumulationcondensate blockage.

Generally, gas injection is applied to improve condensate recovery in gas condensate reservoirs by increasing or maintaining the pressure above dew point pressure. In different gas injection methods such as gas cycling, CO2 injection, and N2 injection, the aim is to keep the pressure in the reservoir higher than the dew point to prevent condensate formation. Gas injection also helps to revaporize the liquid condensate to the gas phase again and let the condensate be recovered.

Abel et al. (1970) described two schemes of gas cycling: full pressure maintenance and partial pressure maintenance. In full pressure maintenance, gas is continuously injected into the reservoir while at the same time condensate is produced from the reservoir. In partial pressure maintenance, gas is injected into the reservoir after primary depletion below the dew point in an attempt to slow further pressure decline and re-vaporize the condensate. Luo et al. (2002) conducted experiments on a real rich gas condensate fluid to investigate condensate recovery based on the two schemes mentioned above. Their results showed that the condensate recovery is higher when injection is done above the saturation pressure. Al-Wadhahi et al. (2006) did simulation work to examine the cyclic gas injection to revaporize liquid dropout in an Omani gas field. In this study, a compositional simulation model was used to confirm the theory of condensate revaporization. The results indicated that cyclic gas injection is a viable production method. This method could improve gas deliverability and enhanced condensate recovery.

Huff-n-puff gas injection is an EOR method normally used in the steam injection in conventional reservoirs. The well is used as both injection well and production well. Meng et al. (2015) conducted experiments on shale cores. Their experiment results show good EOR potential for huff-n-puff gas injection, but field scale study is necessary. In this study, the application and operation of huff-n-puff in the Eagle Ford shale gas condensate reservoir was simulated.

\section{Reservoir Model Description}

Ultra-low permeability shale reservoirs require a large fracture network to maximize well performance. Actually, for shale reservoirs, the large scale fracture network formed by hydraulic fracturing-stimulated reservoir volume (SRV) is required to achieve profitability (Cipolla et al. 2008; Mayerhofer et al. 2008). Those authors discussed about using numerical simulations of explicit fracture networks created in a stimulated reservoir volume to model the physics of flow within a fractured shale reservoir. They added the SRV to obtain reasonable results. In actuality, the mechanism of SRV is not well known. In our simulation model, SRV is also added. Thus, the simulation model includes two regions: the stimulated reservoir region and the un-stimulated reservoir volume. 
The whole shale reservoir is stimulated with 9 transverse fractures. In this simulation work, only one hydraulic fractured reservoir region was simulated on the basis of flow symmetry. Thus, the cumulative condensate and gas production could be obtained simply by multiplying by the number of effective fractures. The simulation model is shown in Fig.1.

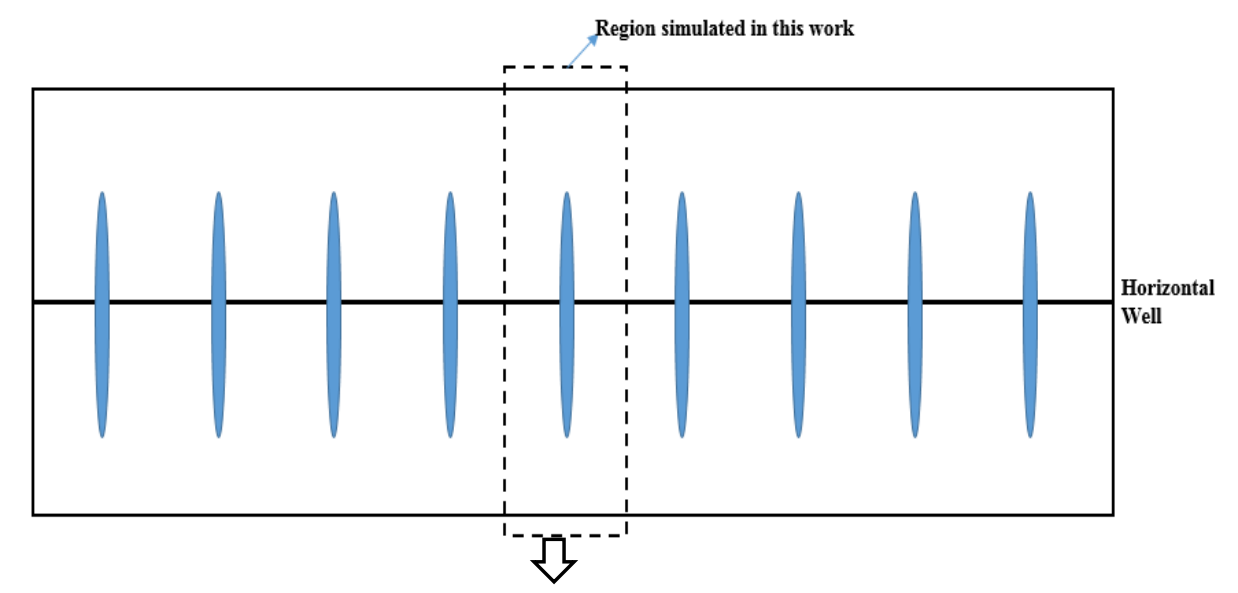

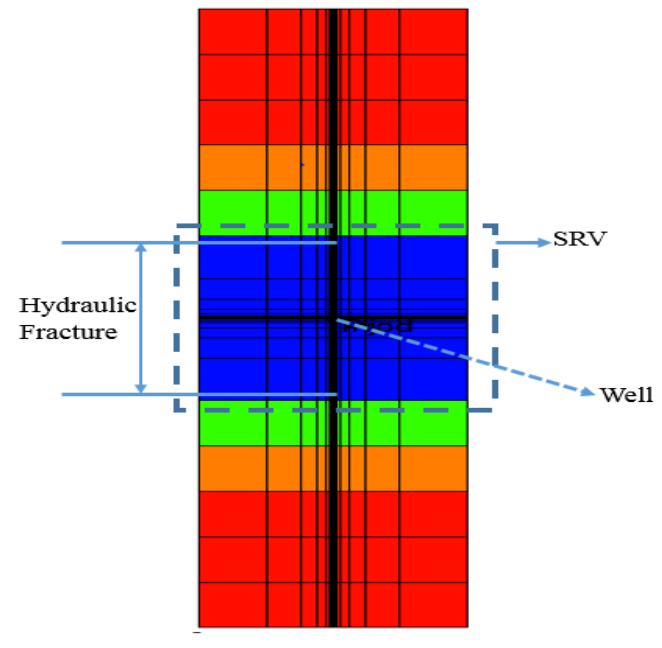

IJ view

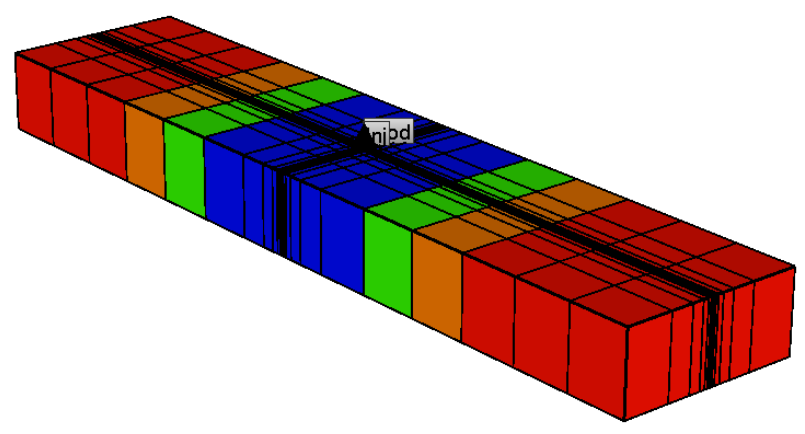

$3 \mathrm{D}$ view

Fig.1. Schematic of simulation model

The reservoir simulation work for the application of huff-n-puff gas injection was performed by using the compositional simulator, GEM in Computer Modeling Group. The dimensions of the shale gas condensate reservoir were $592 \mathrm{ft}$ wide in the I direction, $2724 \mathrm{ft}$ in the $\mathrm{J}$ direction with $724 \mathrm{ft}$ in the SRV area as shown in Fig. 1, and $50 \mathrm{ft}$ in the $\mathrm{K}$ direction. In this reservoir model, the half fracture spacing was $296.25 \mathrm{ft}$ in the I direction, the fracture length was $724 \mathrm{ft}$ in the $\mathrm{J}$ direction, and the fracture height was $50 \mathrm{ft}$ in the $\mathrm{K}$ direction. The half-hydraulic fracture width was $0.5 \mathrm{ft}$. Symmetric flow geometry allows the results to be extrapolated to a larger scale. The reservoir was also modeled as a $21 \times 31 \times 1$ Cartesian grid. For this model, increasing the number of grid blocks has no effect on the simulation results, but the more gird blocks required, the longer the computation times. Thus, these grid blocks were selected to simulate the huff-n-puff gas injection project. 
Also, the reservoir rock properties used in this model were based on the published data in Eagle Ford shale (Wan et al, 2013). The properties of the reservoir are shown in Table 1.

Table 1: Reservoir properties

\begin{tabular}{ccc}
\hline Parameters & value & unit \\
\hline Initial reservoir pressure & 5000 & $\mathrm{psi}$ \\
Reservoir Temperature & 200 & ${ }^{\circ} \mathrm{F}$ \\
Thickness & 50 & $\mathrm{ft}$ \\
Matrix Permeability & 0.0001 & $\mathrm{mD}$ \\
Matrix Porosity & 0.06 & \\
Rock Compressibility & $5.0 \mathrm{E}-06$ & $\mathrm{mD}$ \\
$\begin{array}{c}\text { Hydraulic Fracture } \\
\text { Permeability }\end{array}$ & 100 & $\mathrm{mD}$ \\
Permeability of Matrix & 0.0001 &
\end{tabular}

PVT and compositional data for an Eagle Ford shale gas condensate reservoir fluid sample was obtained from published data (Seo and Anderson, 2012; Li et al. 2015). The fluid model was generated using CMG WinProp. The sample was taken at a depth of $9800 \mathrm{ft}$, the initial pressure was $5000 \mathrm{psi}$, and the temperature was $200{ }^{\circ} \mathrm{F}$. The components of the reservoir fluid were lumped into 14 pseudo-components. Table 2 lists the pseudo-components descriptions used in this model, and the input for the Peng-Robinson equation of state calculations.

As it can be seen from Fig. 2, condensate starts to form when the pressure is lower than the dew point pressure $2750 \mathrm{psi}$. Then, the condensate volume continues to increase until the pressure reduces to 2500 psi when the maximum amount of condensate liquid is reached. After that, as the pressure continues to decrease, the liquid is revaporized and the condensate volume is reduced.

The simulation work was used to determine the application of huff-n-puff gas injection in the field, thus, there was only one well in this model and this well was used as both an injection well and a production well. The producer was subjected to the minimum bottom-hole pressure constraint of $1500 \mathrm{psi}$, and the injection well was subjected to the maximum injection pressure constraint of 4000 psi. The injection and production times are discussed in a later section.

Table 2: Peng-Robinson EOS Fluid Description of Eagle Ford Condensate Lumping

\begin{tabular}{cccccc}
\hline & Fraction & $\mathrm{Pc}(\mathrm{atm})$ & $\mathrm{Tc}(\mathrm{K})$ & Acentric Factor & $\mathrm{MW}$ \\
\hline $\mathrm{CO} 2$ & 0.18 & 72.8 & 304.2 & 0.225 & 44.01 \\
$\mathrm{~N} 2$ & 0.13 & 33.5 & 126.2 & 0.04 & 28.013 \\
$\mathrm{CH} 4$ & 61.92 & 45.4 & 190.6 & 0.008 & 16.043 \\
$\mathrm{C} 2 \mathrm{H} 6$ & 14.08 & 48.2 & 305.4 & 0.098 & 30.07 \\
$\mathrm{C} 3 \mathrm{H} 8$ & 8.35 & 41.9 & 369.8 & 0.152 & 44.097 \\
$\mathrm{IC} 4$ & 0.97 & 36 & 408.1 & 0.176 & 58.124
\end{tabular}




\begin{tabular}{cccccc} 
NC4 & 3.41 & 37.5 & 425.2 & 0.193 & 58.124 \\
IC5 & 0.84 & 33.4 & 460.4 & 0.227 & 72.151 \\
NC5 & 1.48 & 33.3 & 469.6 & 0.251 & 72.151 \\
NC6 & 1.79 & 29.3 & 507.4 & 0.296 & 86.178 \\
NC7 & 1.58 & 27 & 540.2 & 0.351 & 100.205 \\
NC8 & 1.22 & 24.5 & 568.8 & 0.394 & 114.232 \\
NC9 & 0.94 & 22.8 & 594.6 & 0.444 & 128.259 \\
C10+ & 3.11 & 20.686 & 617.7 & 0.4902 & 142.3 \\
\hline
\end{tabular}

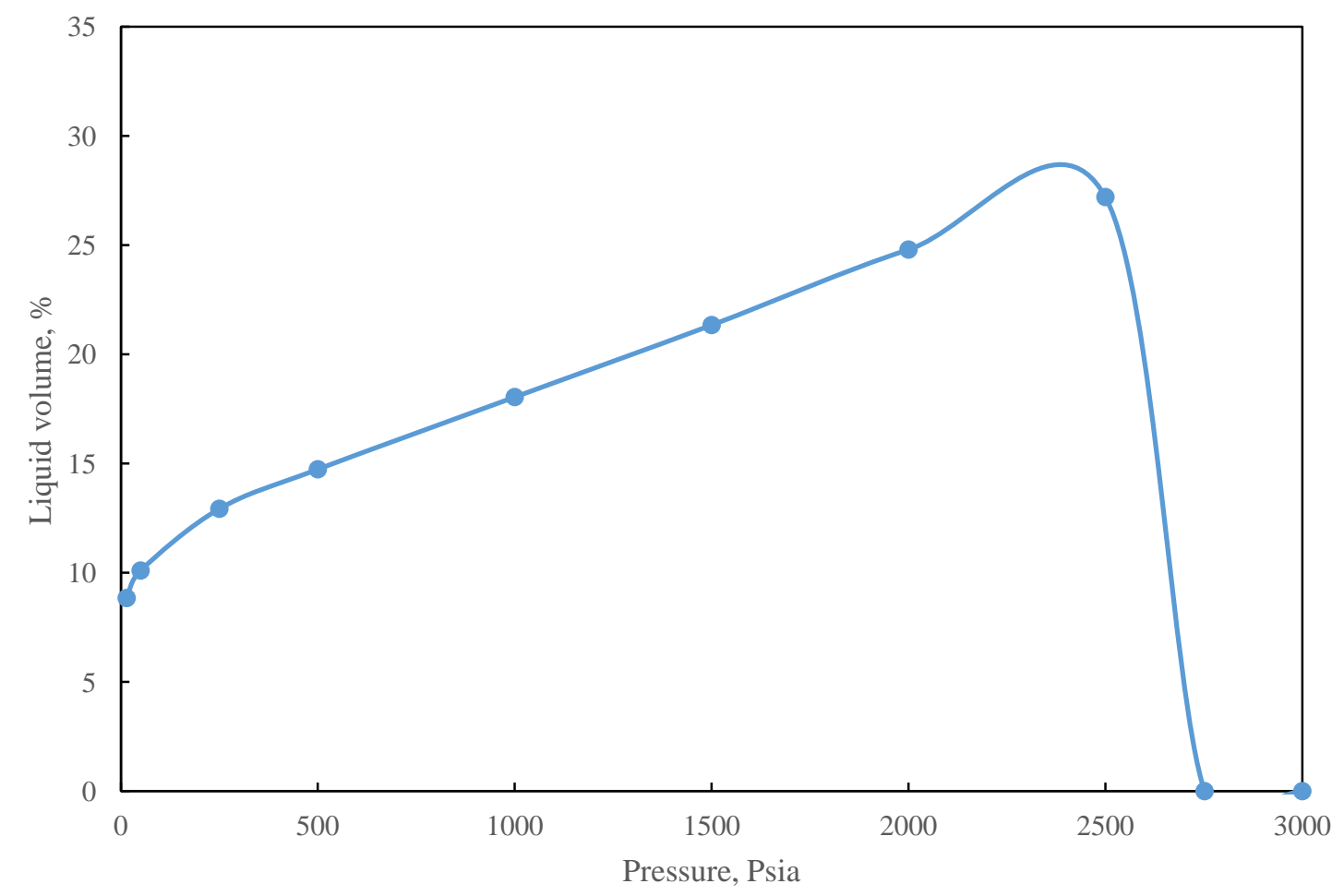

Fig. 2. The liquid dropout curve for CCE experiment at $200^{\circ} \mathrm{F}$ on the gas condensate mixture

The hydraulic fracture was modeled as a 2-ft wide pseudo fracture in order to increase numerical stability (Sanchez-Rivera et al. 2015). The effective fracture grid block permeability was calculated from Equation 1:

$K_{e f f}=\frac{K_{f} W_{f}}{W_{e f f}}$

$\mathrm{K}_{\mathrm{f}}$ is the actual fracture permeability, $\mathrm{W}_{\mathrm{f}}$ is the actual fracture width, and $\mathrm{W}_{\text {eff }}$ is the width of the grid blocks representing the fracture.

In this simulation, a fracture with a permeability of $100 \mathrm{mD}$ and a width of $0.5 \mathrm{ft}$ was modeled as a $2 \mathrm{ft}$ wide fracture with a permeability of $25 \mathrm{mD}$. This was done to improve the stability of the model. 


\section{Results}

\subsection{Start of huff-n-puff}

The life expectancy of an Eagle Ford shale well could be as long as thirty years, production of $40 \%$ of an Eagle Ford shale well can come in the first five years, then followed by a long decline curve as long as thirty years. This means in later years, the wells produce oil and gas at very low volume. Thus, the beginning of huff-n-puff gas injection is an important time for the exploration of the shale gas condensate reservoir.

One cycle of huff-n-puff gas injection was applied in the simulation model at different start times: 5 years, 10 years, and 15 years. The total production time in this work was 25 years. The results of different cases were compared with 25 years of primary depletion. For this single cycle the injection time was 200 days, and the rest time in 25 years was the production period. The results are shown in Fig. 3.

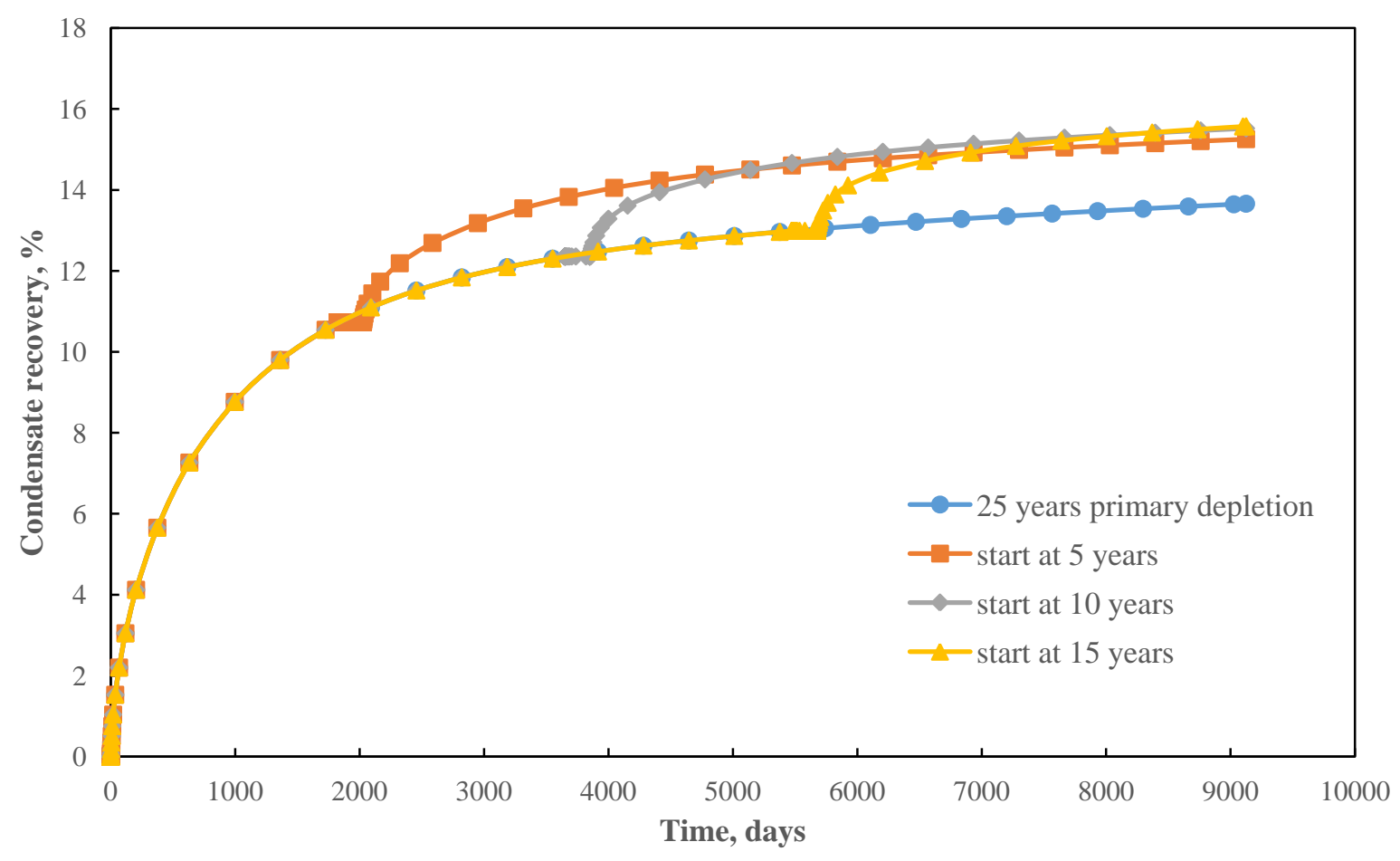

Fig. 3. Condensate recovery for different cases

Compared with the 25 year primary depletion case, the application of huff-n-puff gas injection could increase the condensate recovery. Starting the single cycle of huff-n-puff gas injection after 15 years had an incremental recovery of $1.9 \%$ compared with case without huff-n-puff gas injection. Meanwhile, starting huff-n-puff after 5 years had an incremental recovery factor of 1.5. 
Fig. 4 shows the gas production rate from the primary depletion period. As Fig. 4 indicates, the production decreased very fast in the first 5 years and in the following 20 years the production rate was very slow. In the first year, the gas production rate was $158950 \mathrm{ft}^{3} /$ day and after 15 years the rate decreased to $11767.18 \mathrm{ft}^{3} /$ day. The production rate declined almost $92 \%$, which is a very high value. At 10 years, the rate declined about $85 \%$. The high decline rate is also not only due to the ultra-low permeability, but also due to the accumulation of condensate in the formation. Thus at 15 years both the heavy and light hydrocarbon components were left in the reservoir.

Combined with the gas production decline rate and the effect of the starting time of huff-n-puff, it can be seen that huff-n-puff gas injection is more effective when starting at the later period of primary depletion (when the production rate was decreased around $90 \%$ in this case). If the huffn-puff is applied too early, the primary production rate is not that low and comparing the incremental recovery with the cost of injection process, it is unnecessary. When the huff-n-puff gas injection is applied in the later time, since the production rate is so low, the application of huff-n-puff gas injection can effectively enhance the recovery and increase profits.

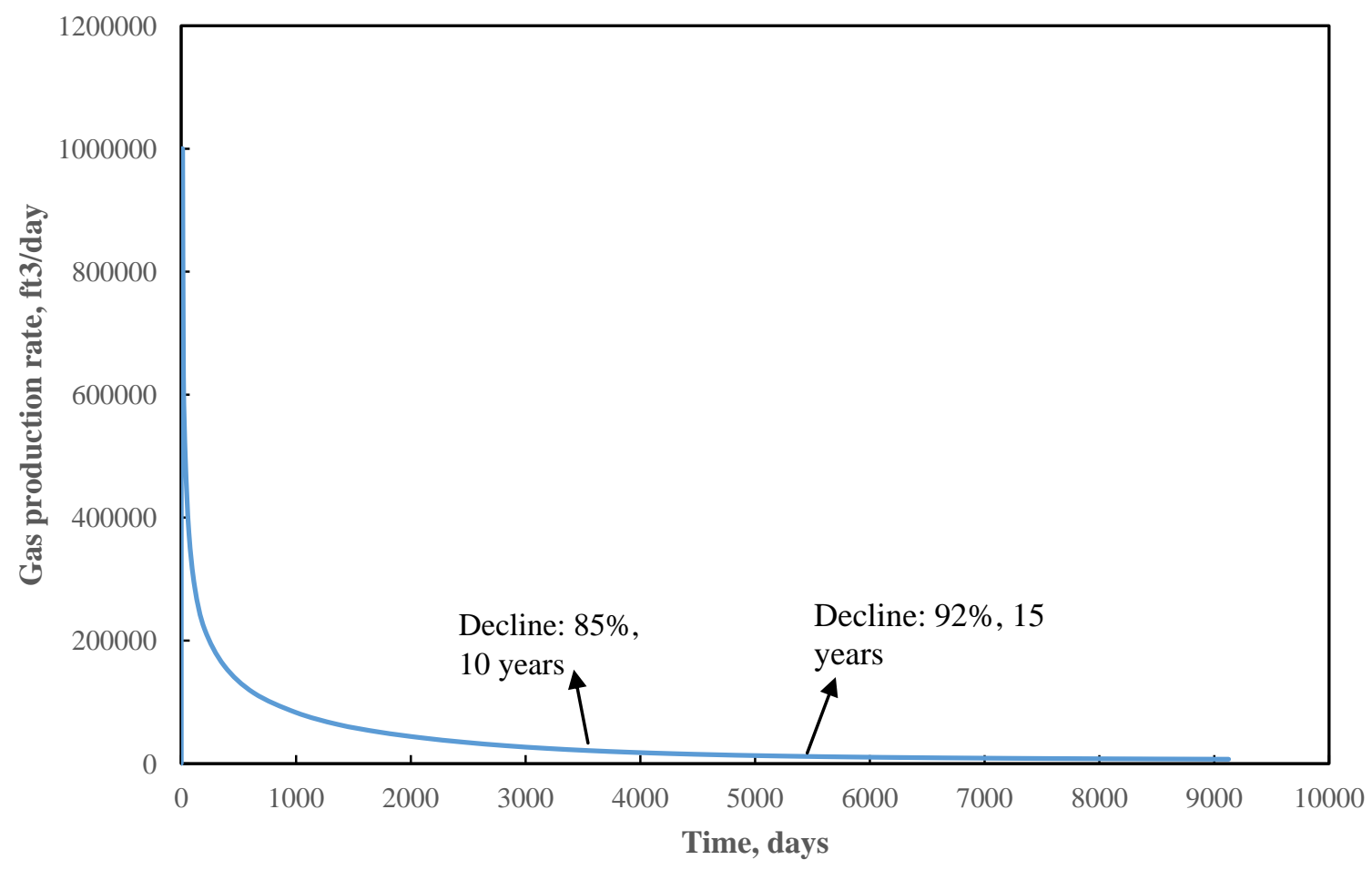

Fig. 4. Gas production rate for 25 years primary depletion

\subsection{Injection Period}

Based on the investigation of huff-n-puff application on other kinds of reservoirs (Sheng, 2015; $\mathrm{Yu}$ et al. 2014), injection time has a very large impact on incremental recovery. The longer injection time means a longer time for pressure to build up in the reservoir. For shale gas condensate reservoirs, the longer pressure build time means more condensate can be revaporized to gas phase, and then more condensate can be recovered during the production period. Though a 
longer injection has greater recovery, the longer injection time also indicates more is gas needed to be injected into the reservoir. This means there can be more costs during the injection. If the costs of injection cannot achieve more profits, the application of huff-n-puff gas injection would fail.

In this section, a series of cases were conducted simulating three cycles of huff-n-puff gas injection after primary depletion. The injection time was varied from case to case while the production time remained same: 200 days. Based on the study of previous section, soaking time was not applied. The three injection times were: 10 days, 50 days, and 100 days. Fig. 5 shows the condensate recovery for the different cases. The condensate recovery increased. It is obvious that when the injection time was increased, the increment of pressure in the reservoir increased. Thus, more condensate was recovered. Fig. 6 shows the condensate saturation after three cycles of huff-n-puff, and it can be seen that the condensate which remained in the reservoir or remained near the fracture in the 100 day injection time case was less than the 10 day injection time case and the 50 day injection time case.

More condensate was recovered from the reservoir when the injection time was longer. However, as mentioned before, longer injection time means higher costs. Thus, the profits of every case were investigated, excluding Taxes and OPEX. In this investigation of profits, we used a low oil price of $40 \mathrm{USD} / \mathrm{bbl}$, and a gas price of $2 \mathrm{USD} / \mathrm{Mscf}$. The purpose of profit analysis in this study is to compare the efficiency of different cases, so an optimized parameter such as injection time can be determined.

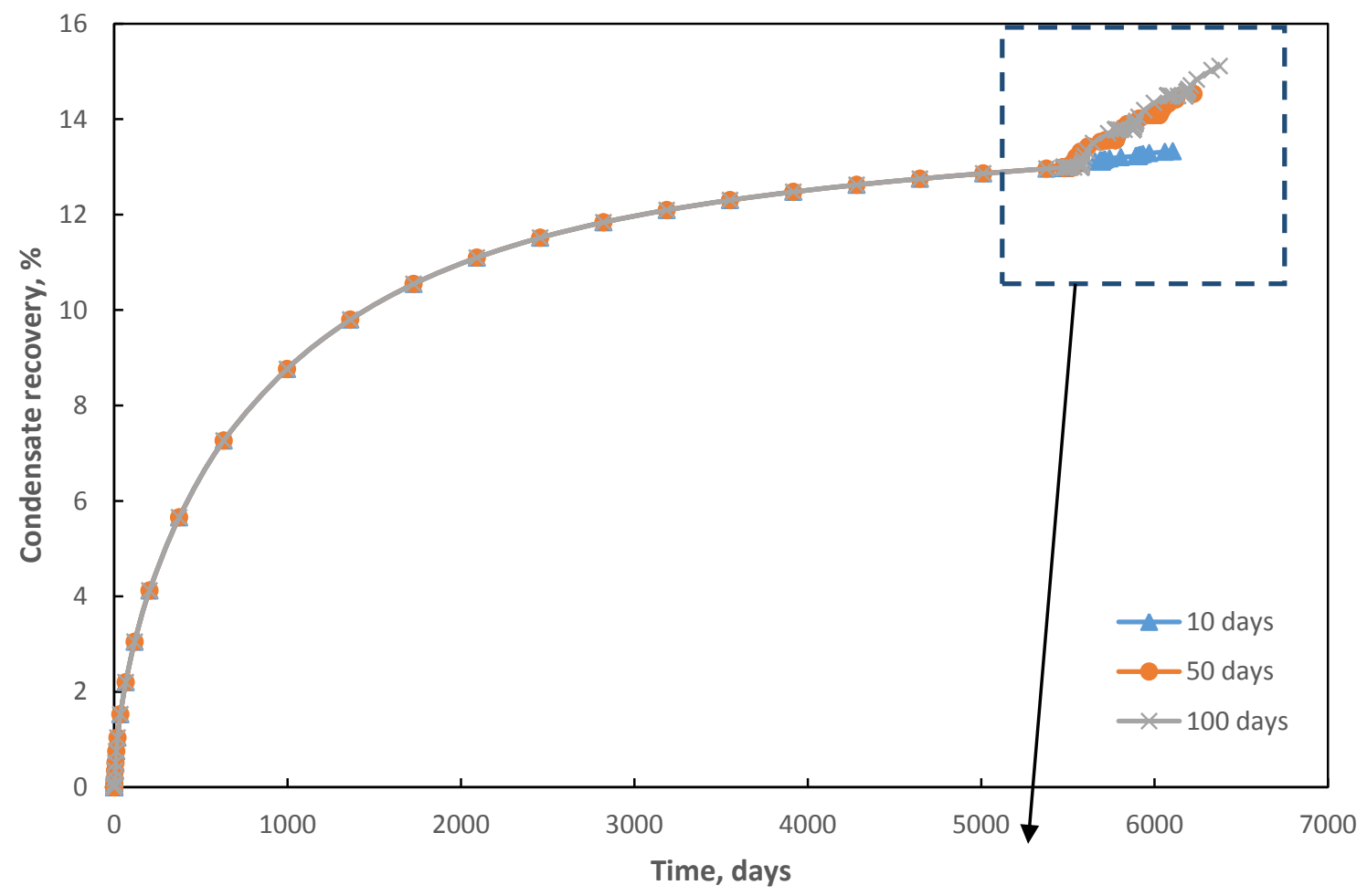




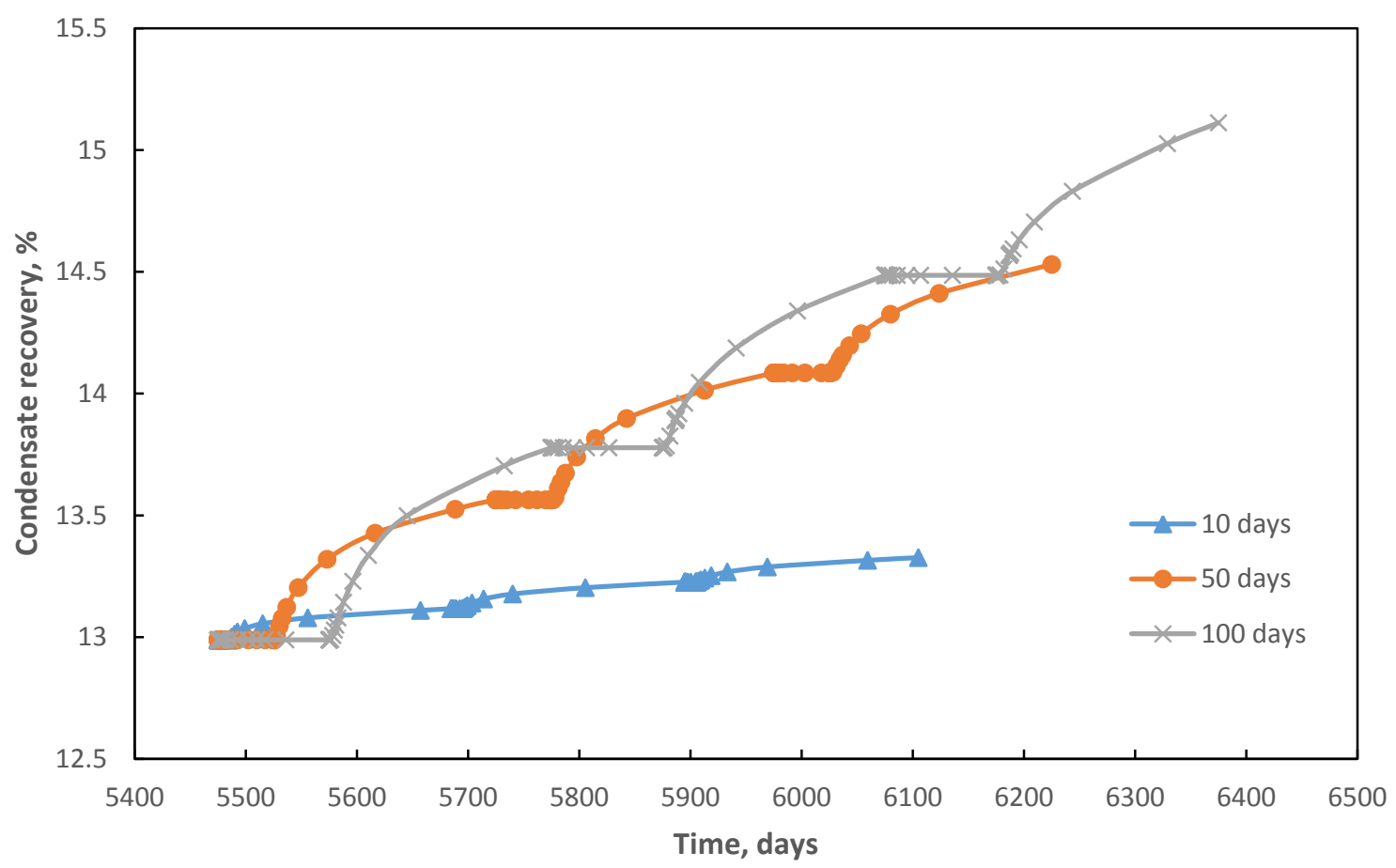

Fig. 5. Condensate recovery for different injection time cases

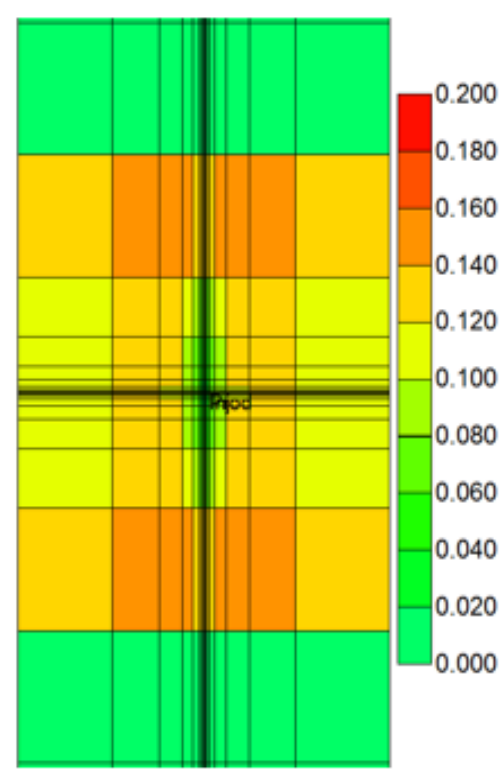

10 days

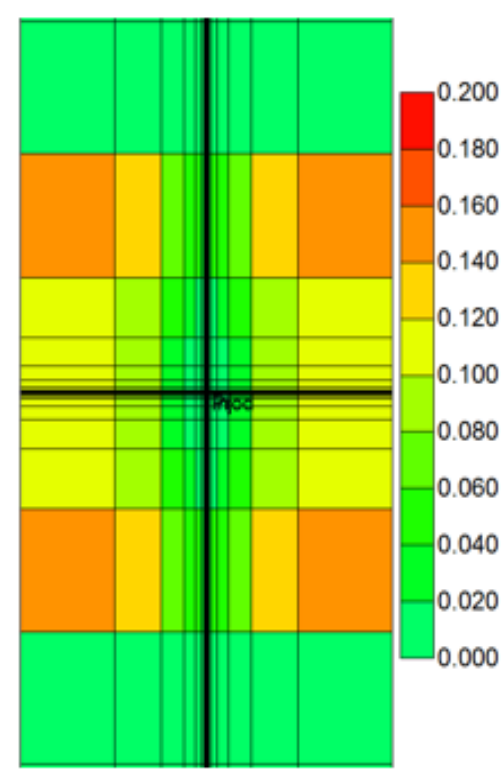

50 days

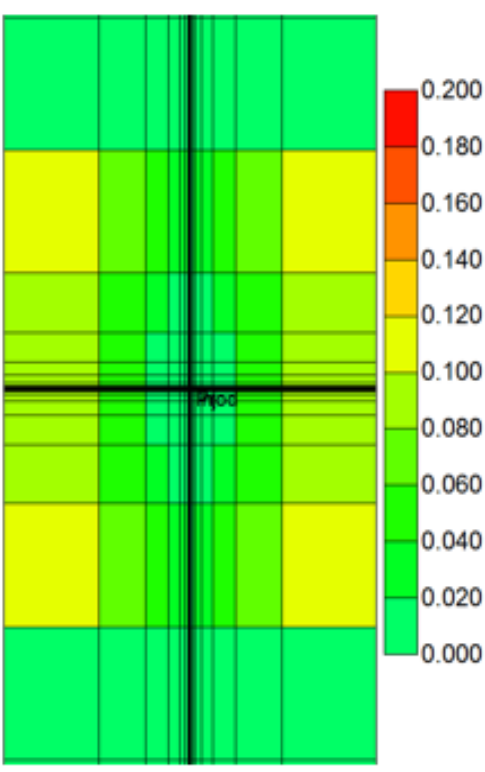

100 days

Fig. 6. Condensate saturation distribution for different injection time cases 
Table 3: Profits for different injection time cases

\begin{tabular}{cccccc}
\hline $\begin{array}{c}\text { Injection } \\
\text { time, days }\end{array}$ & $\begin{array}{c}\text { Condensate } \\
\text { RF,\% }\end{array}$ & Produced oil, bbl & $\begin{array}{c}\text { Injected gas, } \\
\mathrm{ft} 3\end{array}$ & $\begin{array}{c}\text { Produced } \\
\text { gas, ft3 }\end{array}$ & Profit, \$USD \\
\hline 10 & 13.3 & 12933.2 & 30000000 & 315000000 & 1087328 \\
50 & 14.5 & 14113.4 & 117000000 & 381000000 & 1092536 \\
100 & 15.1 & 14678.5 & 164000000 & 407000000 & 1073140 \\
\hline
\end{tabular}

As it can be seen from Table 3, the 100 day injection time case had the highest condensate recovery of $15.1 \%$. However, the profits of 100 days injection time case were the lowest. Compared with the 10 day injection time case and the 50 day injection time case, the 100 day injection time case had a much larger volume of injected gas, and the cost of the injection period was much higher. Compared with the 10 day injection time case, the 50 day injection time case had a higher condensate recovery and the profit was also higher.

It can be concluded that longer injection time does not mean higher profits. Though longer injection time can increase condensate recovery, the costs are much higher and the profits are lower. During the design of the injection period of huff-n-puff gas injection, it is very important to choose the best injection time. As it mentioned before, the condensate saturation is mainly in the near fracture region, as shown in Fig.7. From Fig. 8, it can be seen for the 50 day injection time case, the condensate saturation near the fracture region was lower. This means that during the 50 day injection, the pressure of this near fracture region increased, and the condensate was revaporized.

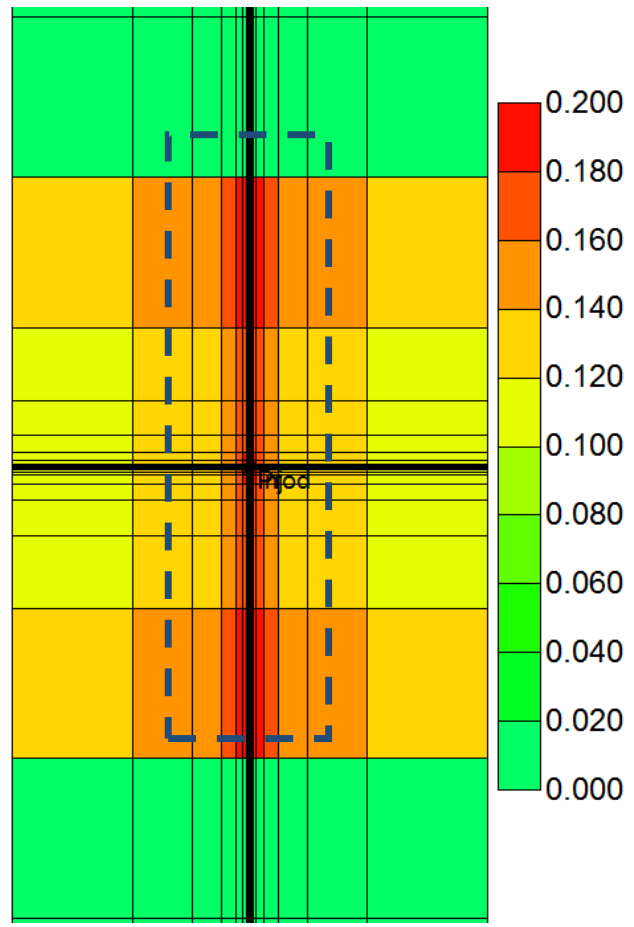

Fig. 7. Condensate saturation after 15 years primary depletion 


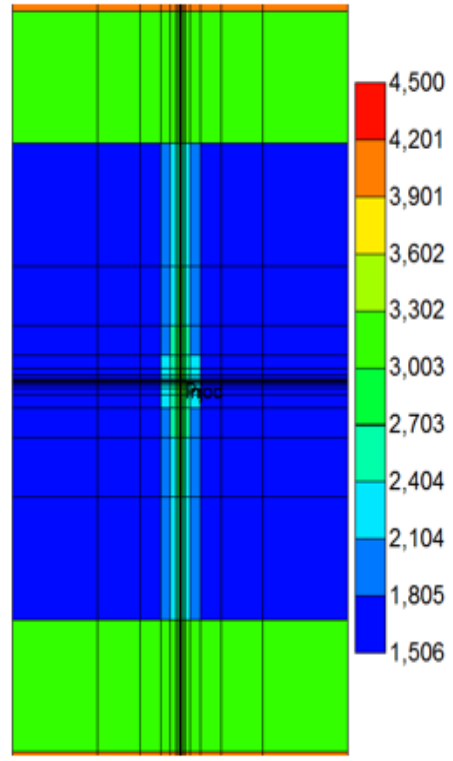

10 days
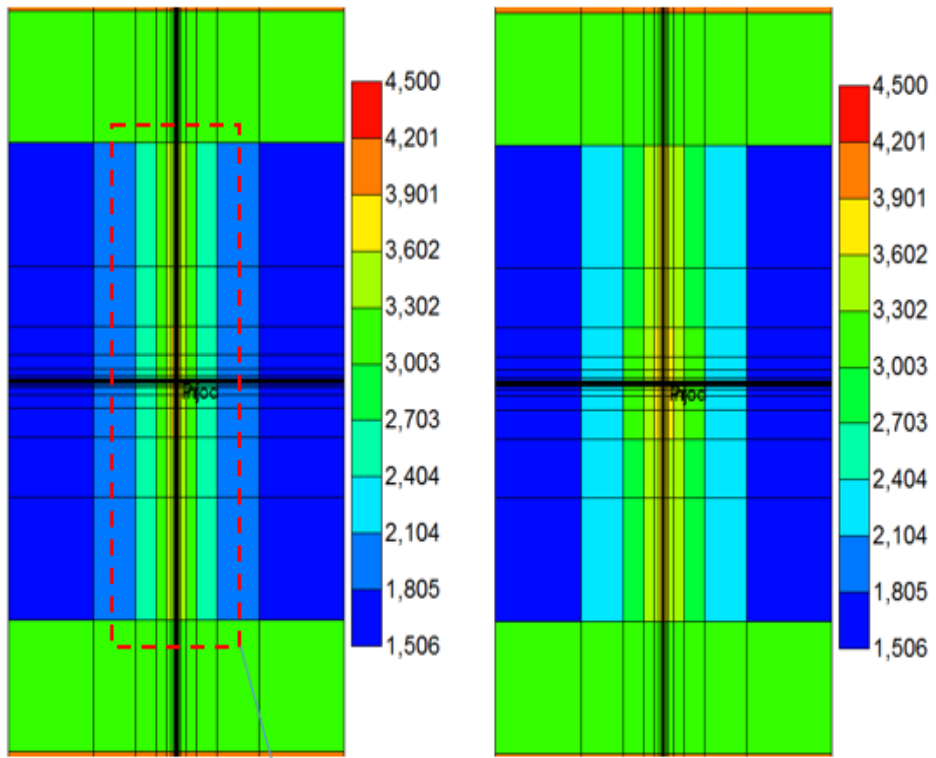

"Mainly condensate region

50 days

100 days

Fig. 8. Pressure distribution after $1^{\text {st }}$ cycle of injection for different injection time cases

Thus, the optimized injection time is thatduring the injection time, the pressure of the main condensate region in the reservoir can be increased higher than dew point pressure. The condensate can be revaporized to gas phase, and both condensate production and gas production can be increased.

\subsection{Soaking time}

The effect of soaking period on condensate recovery is investigated in this section for the application of huff-n-puff in a shale oil reservoir. A series of simulations was conducted using different soaking periods: 0, 50 days, and 100 days. In these three cases, two cycles were simulated: 100 days of injection and 200 days of production. It can been seen from Fig. 9 that all three cases had the similar condensate recovery, but the simulation without a soaking period had the largest condensate recovery $(14.5 \%)$. The simulation with the longest soaking time (100 days) had the smallest recovery $(14.23 \%)$.

The results from the three simulations indicate that these are no benefits to applying a longer soaking time. Longer soaking time means the longer waiting time, and this reduces the production period. Also, longer soaking time had the smallest recovery in these three simulation cases. This means that for the application of huff-n-puff gas injection in shale gas condensate reservoir, short soaking time or even no soaking time would be better.

The reason why soaking time has a negative effect in this case is related to the gas condensate fluid property. In these three simulation cases, the injection pressure was already set to a high value: 4000 psi. When the gas was injected into the formation, the pressure of the region near the fracture increased rapidly. The pressure increased to higher than dew point pressure, the condensate was revaporized to gas phase, and the oil (condensate) saturation decreased. 
Though the injected gas could flow further into the reservoir and increase the further region pressure when the well was shut in and the soaking period was applied, the pressure of the region near the fracture decreased compared to the value when the well was just shut in. This is because the pressure in this near fracture region transferred to the further region in the reservoir. When the pressure decreased, the revaporized condensate could be formed into liquid again. The condensate saturation also increased again in the near fracture region, as shown in Fig. 10.

With this in mind, it is clear that for the application of huff-n-puff in shale gas condensate reservoirs, shorter injection or even no soaking time is preferred. If injection pressure is much higher than dew point pressure, then adding a short soaking time will be better because even if the near fracture region pressure transfers to the further region, the pressure will still be higher than dew point pressure, and the condensate will be revaporized to gas phase. However if the injection pressure is not that much higher than dew point pressure, the soaking time could have a negative effect.

Also, in a large scale shale gas condensate reservoir, the condensate is mainly accumulated near the fracture region, thus, for the purpose of increasing condensate recovery, increaseof this region's pressure is the main objective.

The study in this section indicates that shorter or no soaking time is needed during a huff-n-puff operation in shale gas condensate reservoirs.

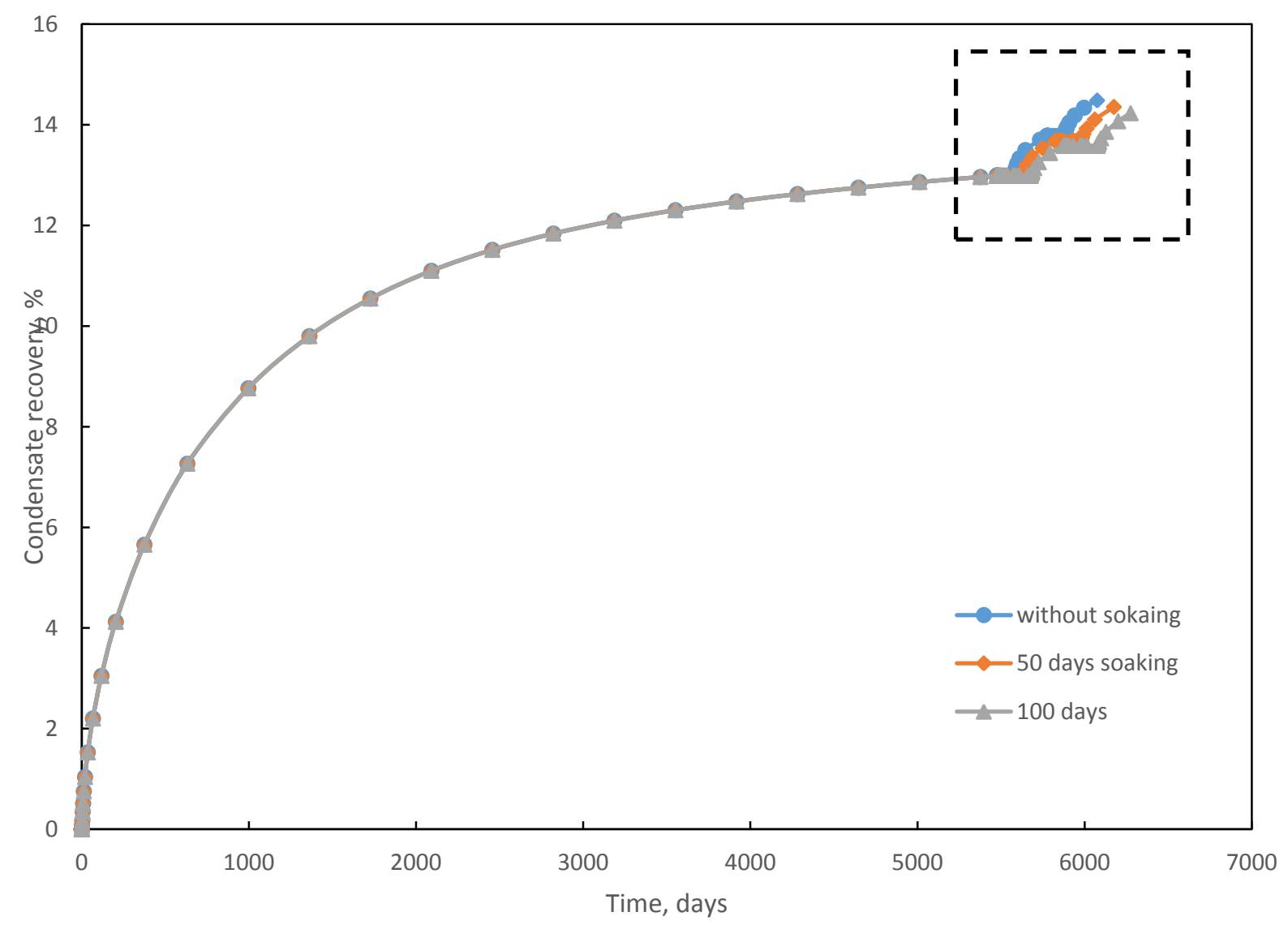

Fig. 9. Soaking time effect on condensate recovery 


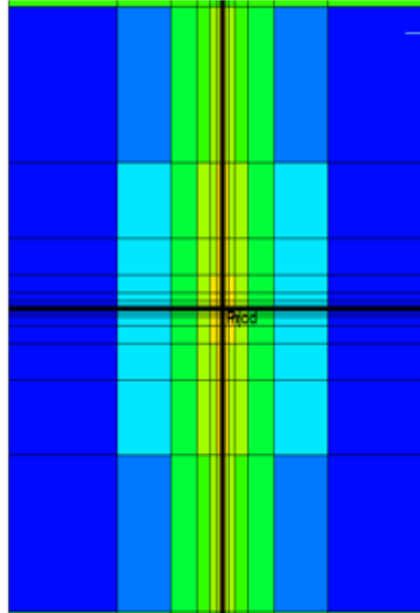

No soaking

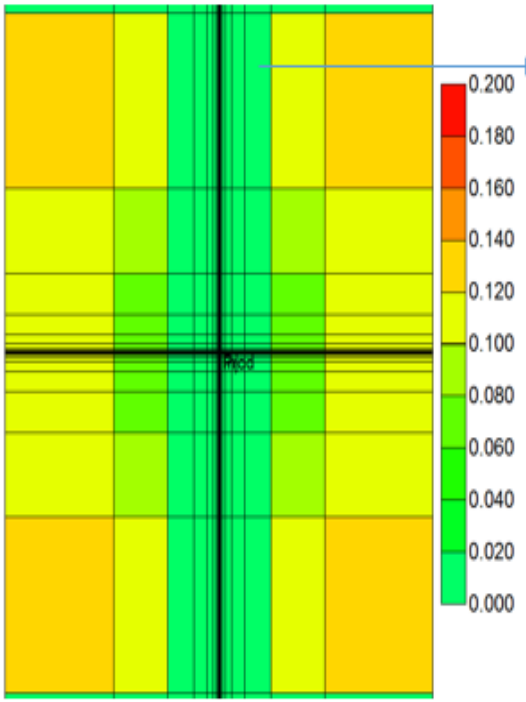

No soaking

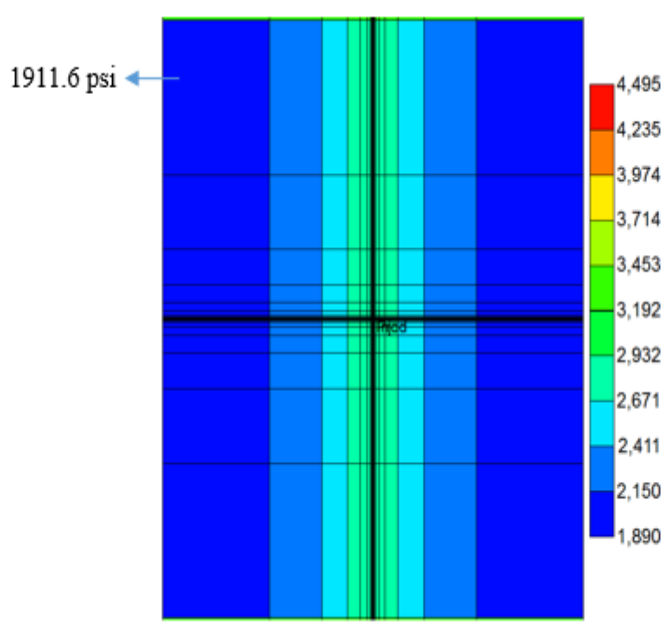

100 days soaking

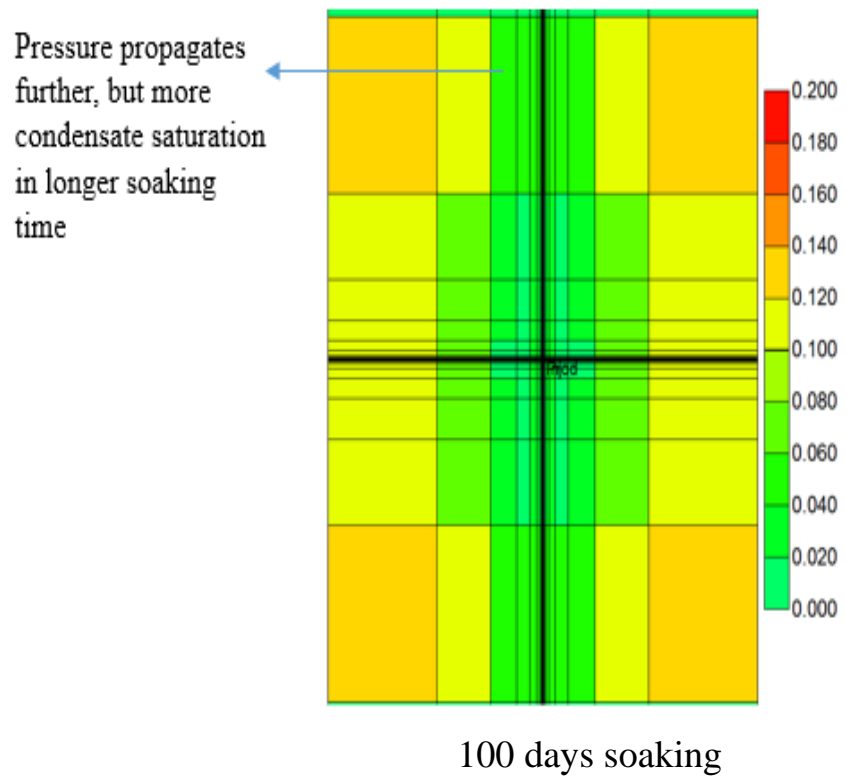

Fig. 10. Pressure and condensate saturation comparison between no soaking case and 100 days soaking time case

\subsection{Number of huff-n-puff cycles and production period}

The huff-n-puff cycle number is also a very important parameter that needs to be seriously taken into account during the application of the huff-n-puff gas injection method in shale gas condensate reservoirs. 11 cycles of huff-n-puff were simulated to investigate the efficiency of huff-n-puff over multiple cycles. Every cycle consisted of 50 days of injection and 200 days of production. Based on the previous study, soaking time was not used in this model. Fig. 11 shows the condensate recovery and the pressure. 


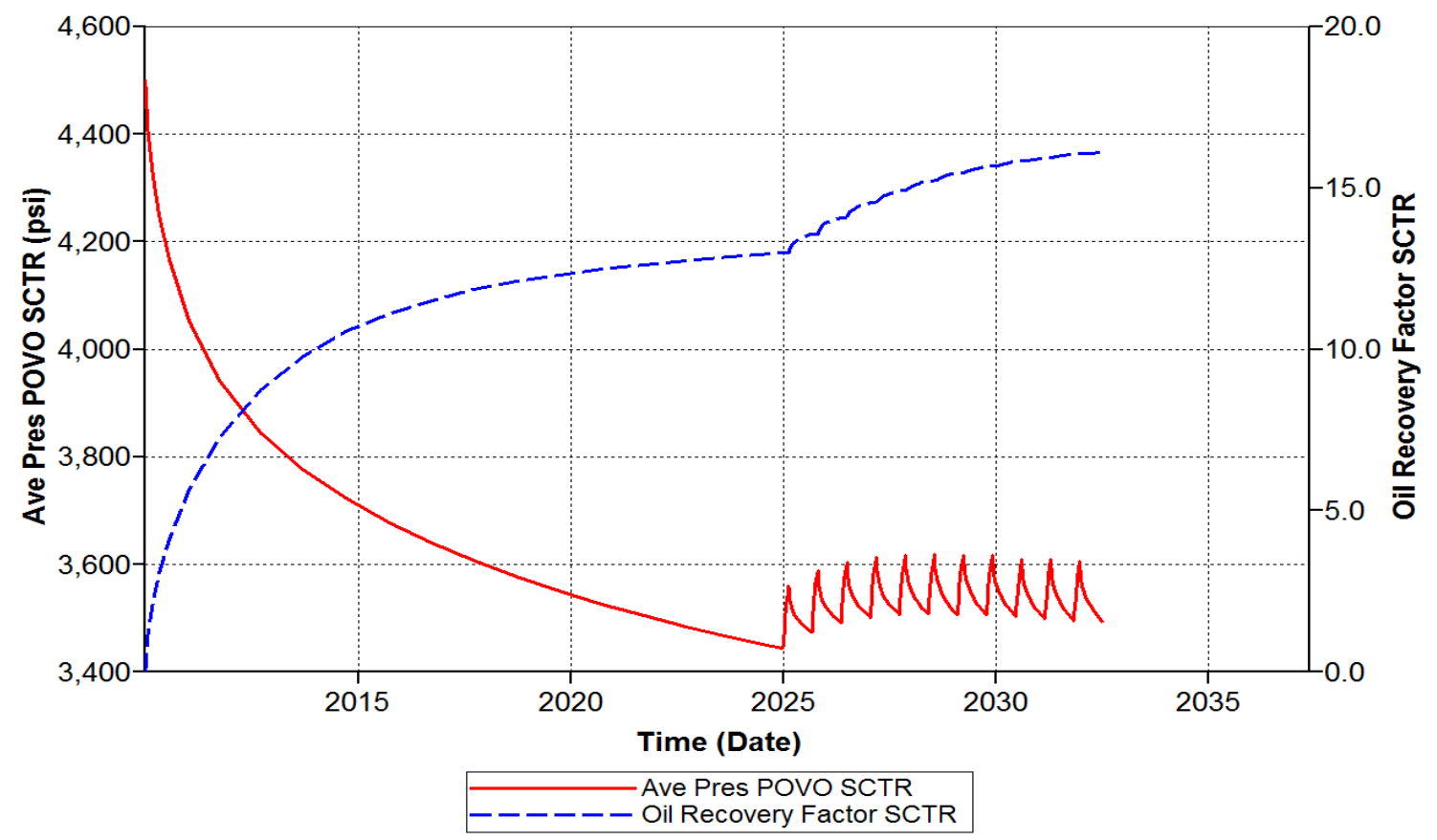

Fig. 11. Condensate recovery and average pressure for 11-cycles huff-n-puff gas injection

It can be seen in Fig. 11 that the condensate recovery increased to $16.12 \%$ after 11 -cycles of huff-n-puff gas injection. The total production time, including primary depletion time and huff-npuff gas injection time, was 8225 days. The comparison of this 11 -cycle gas injection after 15 years of primary depletion and 8225 days of primary depletion is shown in Fig. 12. The incremental condensate recovery by the application of huff-n-puff gas injection was $3 \%$.

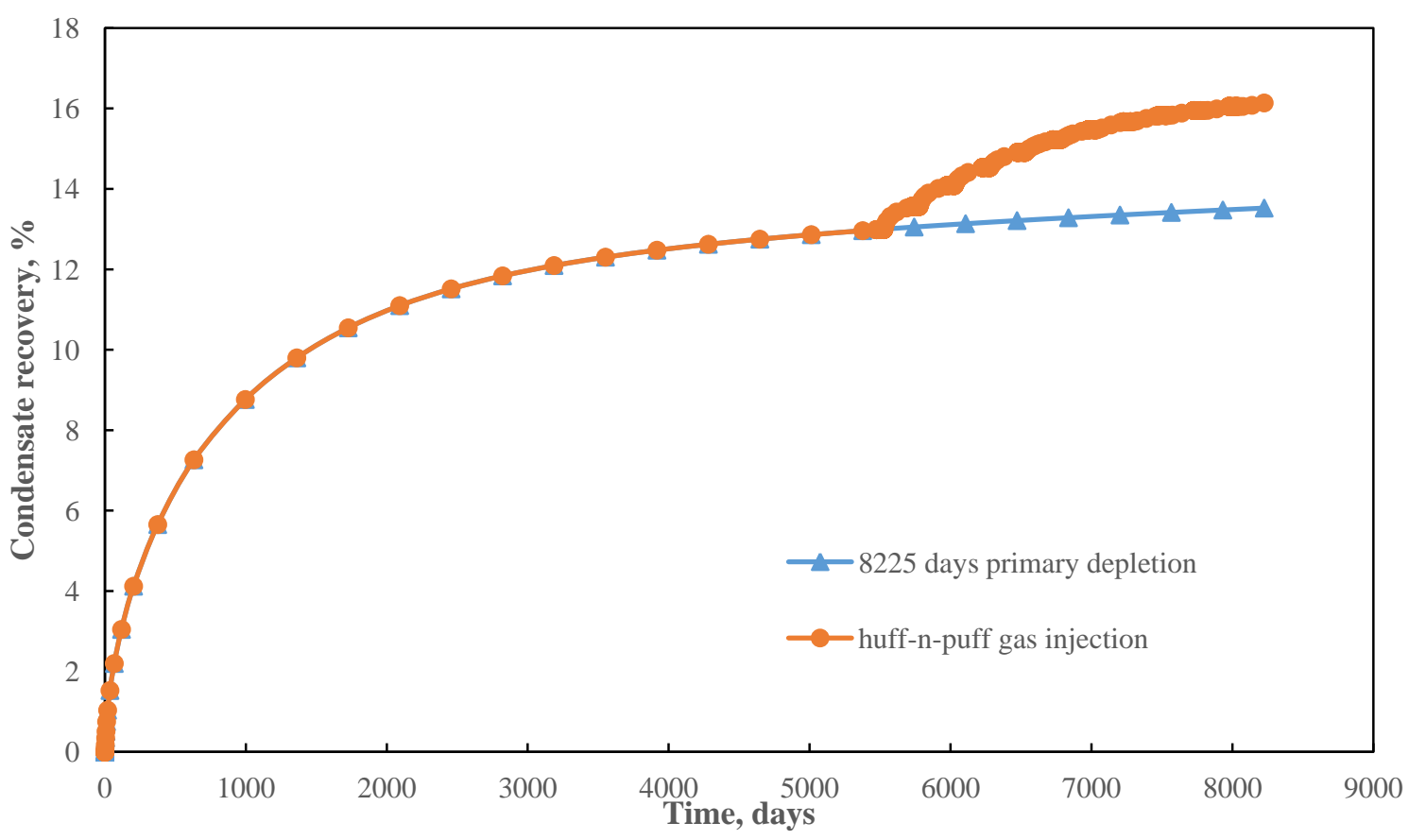

Fig. 12. Condensate recovery comparison between huff-n-puff gas injection and primary depletion 
Fig. 13 shows the gas production rate, and it can be seen that during the production period of every cycle, the production rate was actually high at the end of the production period. According to the previous study, it is better to start huff-n-puff gas injection when the production rate decreases to a low value. In these 11-cycles of huff-n-puff, the rate decreased about $65 \%$ at the end of every production period. Thus, the period of this production should be increased. In a fixed operation time, the increased production time means the fewer cycles of huff-n-puff gas injection, the less cost. According to this production rate, if we want the production rate in the production period to be decreased about $90 \%$, then the production time should be increased to 400 days.

Based on this relationship between decline rate and production time, another huff-n-puff gas injection project was conducted. In this simulation, the injection time was the same as the previous one: 50 days, and based on the previous study, soaking time was also not taken into account. The production time was increased from 200 days to 400 days. The total exploration time of this case was same as the 11-cycles of huff-n-puff gas injection: 8825 days. Based on this different time, only 6 cycles were run in this new huff-n-puff gas injection project. Fig. 14 shows the condensate recovery comparison between 11-cycles of huff-n-puff and 6-cycles of huff-npuff.

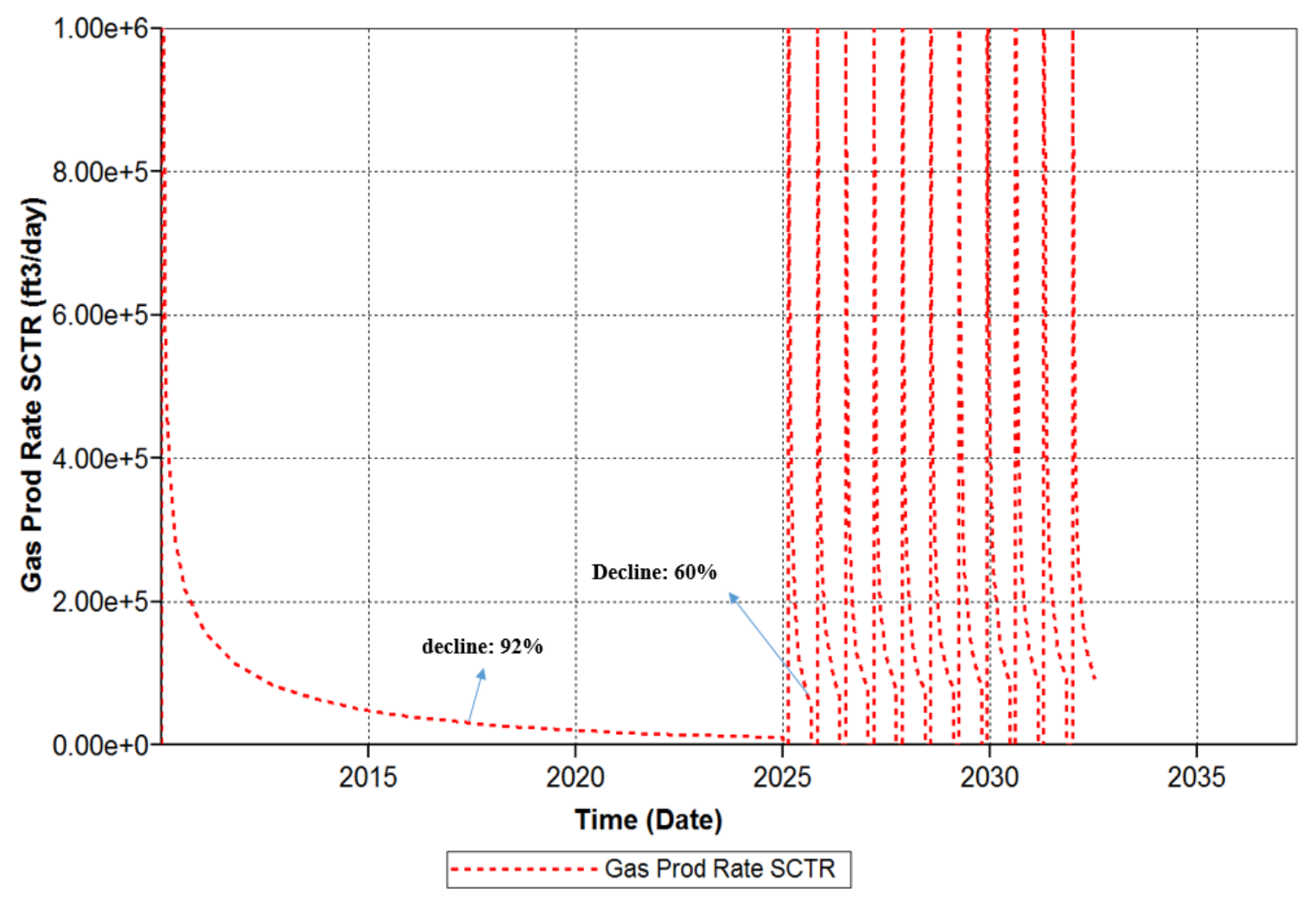

Fig. 13. Production rate in 11-cycles huff-n-puff simulation work 


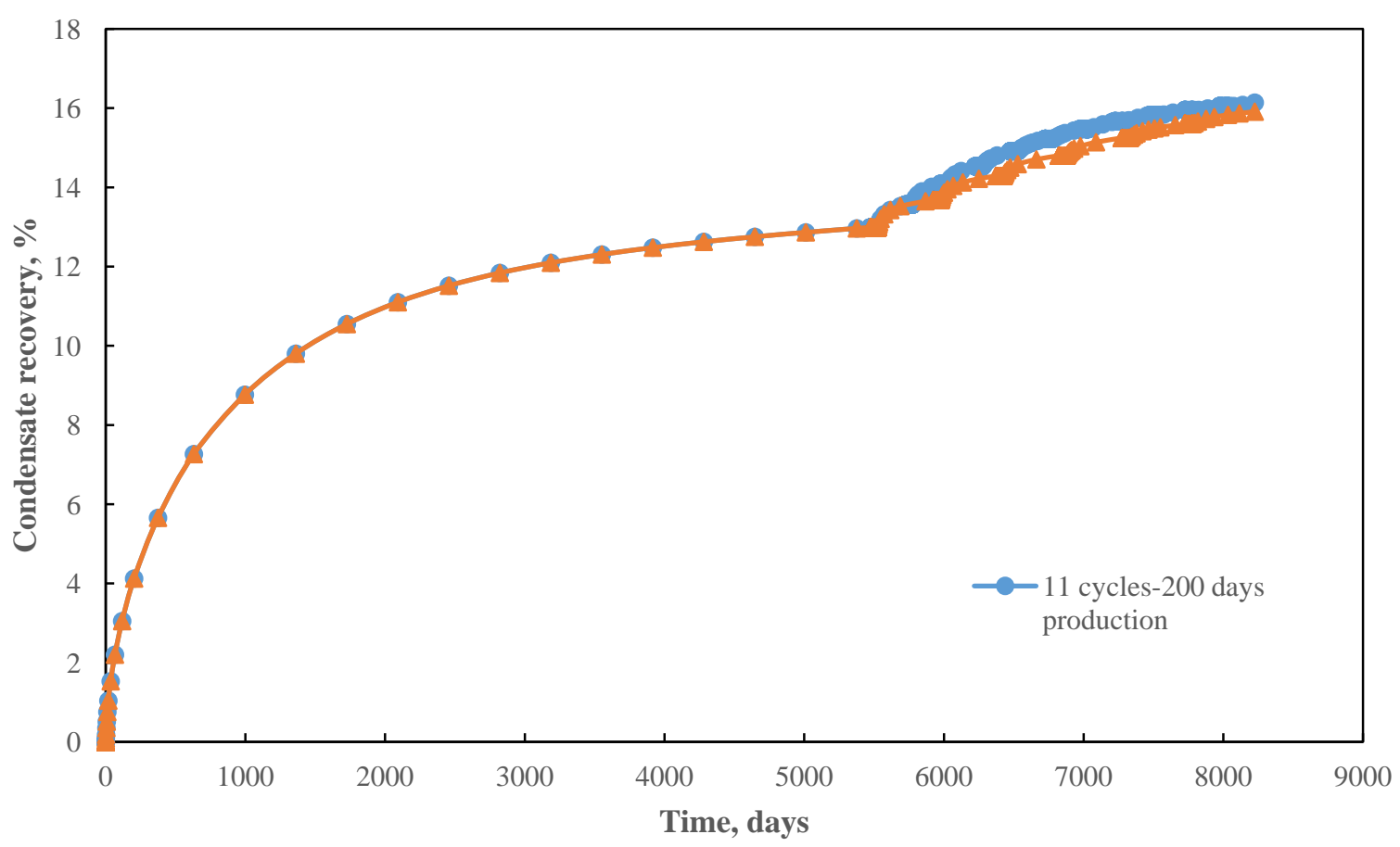

Fig. 14. Condensate recovery comparison between 11-cycles huff-n-puff and 6-cycles huff-n-puff

The condensate recovery was $16 \%$ in 6-cycles of huff-n-puff gas injection, and for 11-cycles of huff-n-puff gas injection, the condensate recovery was only $0.12 \%$ higher than that in 6-cycles of huff-n-puff. This indicates that the start of production time in huff-n-puff gas injection should follow the same optimization principle for the end time of primary depletion. By following this principle, fewer huff-n-puff cycles are needed to increase the condensate recovery. Also, fewer cycle numbers means less gas is needed to be injected into reservoir. This means lower costs for huff-n-puff gas injection projects. Table 4 shows the profits analysis for different cycle numbers of huff-n-puff gas injection and primary depletion. 6 cycles of huff-n-puff with 400 days production time had higher profits.

Table 4: Profits analysis for different cycle numbers of huff-n-puff gas injection and primary depletion.

\begin{tabular}{ccccccc}
\hline & $\begin{array}{c}\text { Condensate } \\
\text { RF,\% }\end{array}$ & $\begin{array}{c}\text { Produced } \\
\text { oil, bbl }\end{array}$ & $\begin{array}{c}\text { Produced gas, } \\
\mathrm{ft}^{3}\end{array}$ & $\begin{array}{c}\text { Injected gas, } \\
\mathrm{ft3}\end{array}$ & $\begin{array}{c}\text { Cumulative } \\
\text { Profits, } \\
\text { \$USD }\end{array}$ & $\begin{array}{c}\text { Profits } \\
\text { incremental, } \\
\text { \$USD }\end{array}$ \\
\hline Primary & 13.5 & 13136.2 & 300000000.0 & N/A & 1125448.0 & N/A \\
$\begin{array}{c}11 \text { cycles, 200 days } \\
\text { production }\end{array}$ & 16.1 & 15675.5 & 678226112.0 & 412651936.0 & 1158168.8 & 32720.8 \\
$\begin{array}{c}6 \text { cycles, } 400 \text { days } \\
\text { production }\end{array}$ & 16.0 & 15453.5 & 234300000.0 & 526000000.0 & 1201540.0 & 76092.0 \\
\hline
\end{tabular}




\section{Conclusions}

- Huff-n-puff is an effective method to enhance condensate recovery in shale gas condensate reservoir.

- Huff-n-puff gas injection is more effective when started at the later time. If huff-n-puff is applied too early, the production rate is not too low, and by comparing the profits of incremental recovery with the cost of injection process, it is not practical.

- An optimized injection time should be selected so that during this injection time, the pressure of the main condensate region in the reservoir can be increased higher than dew point pressure.

- There is no benefit to applying a long soaking time. For the application of huff-n-puff gas injection in the shale gas condensate reservoir, a short soaking time or even no soaking time would be better.

- The cycle number of huff-n-puff is combined with the injection time, soaking time, and production time. For a fixed time of exploitation, more cycles of huff-n-puff gas injection do not mean higher profits. The cycle number should depend on the optimized injection time and optimized production time.

\section{Acknowledgement}

The work presented in this paper is supported by the Department of Energy under Award Number DE-FE0024311.

\section{References}

Abel, W., Jackson, R.F., Wattenbarger, R.A. "Simulation of a Partial Pressure Maintenance Gas Cycling Project with a Compositional Model, Carson Creek Field, Alberta." J Pet Technol 22 (1): 38-46, SPE-2580-PA, January 1970. http://dx.doi.org/10.2118/2580-PA.

Al-Wadhahi, M., Boukadi, F. H., Al-Bemani, A., Al-Maamari, R., and Al-Hadrami, H. "Huff' n puff to revaporize liquid dropout in an Omani gas field." Journal of Petroleum Science and Engineering 55 (1): 67-73, 2007.

Cipolla, C. L., Warpinski, N. R., Mayerhofer, M. J., Lolon, E., and Vincent, M. C. "The Relationship between Fracture Complexity, Reservoir Properties, and Fracture Treatment Design.” In Paper SPE-115769-MS presented at SPE Annual Technical Conference and Exhibition, Denver, Colorado, USA, 21-24 September, 2008. doi:10.2118/115769-MS.

Kuenen, J.P. "On Retrograde Condensation and the Critical Phenomena of Two Substances," Commun. Phys. Lab. U. Leiden, 1892.

Kurata, F. and Katz, D. L. "Critical Properties of Volatile Hydrocarbon Mixtures." Presented in AICHE, 1942.

Luo, K., Li, S., Zheng, X., Chen, G., Dai, Z., and Liu, N. "Experimental Investigation into Revaporization of Retrograde Condensate by Lean Gas Injection" In: paper SPE 68683MS presented at SPE Asia Pacific Oil and Gas Conference and Exhibition, Jakarta, Indonesia, 17-19 April, 2002. 
$\mathrm{Li}, \mathrm{Y}$., and $\mathrm{Pu}, \mathrm{H}$. "Modeling Study on $\mathrm{CO} 2$ Capture and Storage in Organic-Rich Shale." In Paper CMTC-439561-MS presented at Carbon Management Technology Conference, Sugar Land, Texas, 17-19 November, 2015. doi:10.7122/439561-MS.

Meng, X., Yu, Y., Sheng, J.J., Watson, and M., Mody, F., “An Experimental Study on Huff-nPuff Gas Injection to Enhance Condensate Recovery in Shale Gas Reservoirs." In Paper URTeC-2153322 presented at the Unconventional Resources Technology Conference, San Antonio, Texas, USA, 2015.

Moses, P.L. "Engineering Applications of Phase Behavior of Crude Oil and Condensate Systems." J Pet Technol 38 (7): 715-723, 1986. http://dx.doi.org/10.2118/15835-PA.

Mayerhofer, M. J., Stutz, H. L., Davis, E. J., and Wolhart, S. L. "Optimizing Fracture Stimulation Using Treatment-Well Tiltmeters and Integrated Fracture Modeling." SPE Prod \& Oper 21 (2): 222-229, 2006. doi:10.2118/84490-PA.

Sanchez-Rivera D, Mohanty K, Balhoff M. "Reservoir simulation and optimization of Huff-andPuff operations in the Bakken Shale" J. Fuel (2015), 147: 82-94.

Sheng, J. J. "Increase Liquid Oil Production by Huff-n-Puff of Produced Gas in Shale Gas Condensate Reservoirs." Journal of Unconventional Oil and Gas Resources 11: 19-26, 2015a. http://doi:10.1016/j.juogr.2015.04.004.

Standing, M.B. "Volumetric and Phase Behavior of Oil Field Hydrocarbon Systems" Richardson, Texas, 1977.

Seo, M. and Anderson, T. "Liquid form Shale Reservoir Description\& Dynamic/ Phase 2." research progress report, 2012.

Wan, T., Sheng, J. J., and Soliman, M. Y. "Evaluate EOR Potential in Fractured Shale Oil Reservoirs by Cyclic Gas Injection." In: Paper SPE-168880-MS presented at Unconventional Resources Technology Conference, Denver, Colorado, USA, 12-14 August, 2013. doi:10.1190/URTEC2013-187

Yu, W., Lashgari, H., and Sepehrnoori, K. "Simulation Study of CO2 Huff-n-Puff Process in Bakken Tight Oil Reservoirs." In Paper SPE-169575-MS presented at SPE Western North American and Rocky Mountain Joint Meeting, 17-18 April, 2014. http://dx.doi.org/10.2118/169575-MS. 